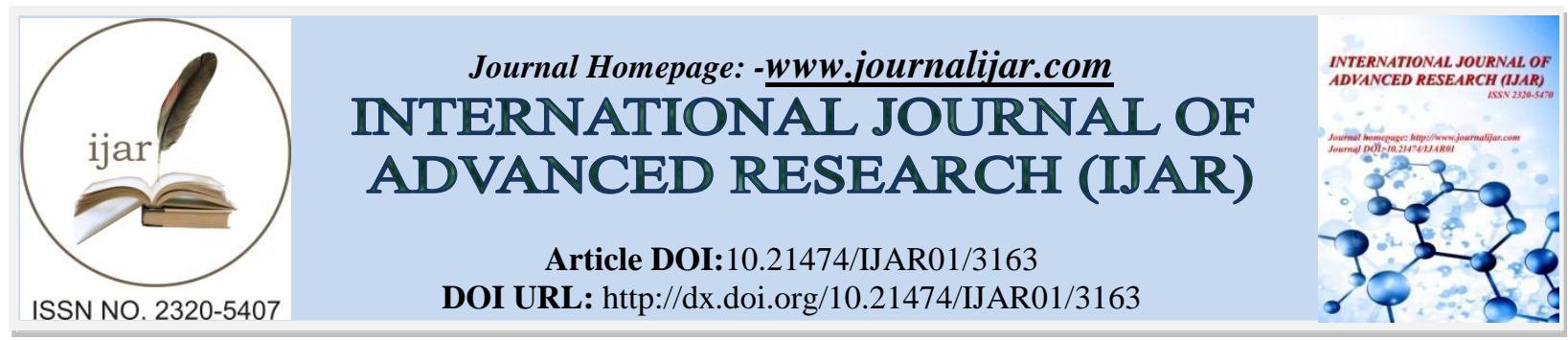

RESEARCH ARTICLE

\title{
FOUNDATIONS AND IMPLICATIONS OF COMPETITIVE INERTIA IN AIRLINES BUSINESS: A STUDY OF THE NEPALI AIRLINES INDUSTRIES
}

\author{
Dipak Prasad Bastola ${ }^{1}$ and Krishna Aryal ${ }^{2}$. \\ 1. PhD Scholar, Kathmandu University School of Management, Nepal. \\ 2. MPhil Scholar, Kathmandu University School of Management, Nepal.
}

\section{Manuscript Info}

Manuscript History

Received: 09 December 2016

Final Accepted: 17 January 2017

Published: February 2017

Key words:-

Competitive inertia, Tactical actions,

Strategic actions, Domestic airlines

\begin{abstract}
This paper explores the foundations and implications of competitive inertia in Nepali airlines industry. Eighty respondents answered on a structured Likert typequestionnaire in two stages. Results of the field study found a significant relationship between competitive inertia and tactical actions but no relation of competitive inertia with strategic actions. Variables for tactical actions included price cut, promotion with other non-airlines companies and commission to agents while variables for strategic actions included new services and frequent flyer programs. The study found that past history for inertia variedbetween tactical and strategic actions, the previous being determined more by performance and the second by growth in markets. These outcomesadvocate the action of two separate models of the organizational learning, one reactive, the other experimental and that there is competitive inertia in the strategic actions and no competitive inertia in tactical actions. Implications of the findings are discussed.
\end{abstract}

Copy Right, IJAR, 2017,. All rights reserved.

\section{Introduction:-}

Organizational inertia is defined as the tendency of a mature organization to continue on its current path(Creative Advantage, n.d.). This inertia can be described as being made up of two fundamentals, viz.: resource rigidity and routine rigidity. Resource rigidity, as stated in Creative Advantage, stems from areluctance to invest, while regular rigidity stems from apowerlessness to change the patterns and reason that underlie those investments. Resource rigidity relates to the motivation to respond, regularstrictness to the structure of that response.

In the words of(Miller, Danney; Chen Ming Jer, 1994) competitive inertia is defined as the level of activity that a firm shows when altering its competitive position in areas such as pricing, marketing, new product or facility introductions, and market reach. Inertia is argued to be determined by managers' incentives to act, their consciousness of action alternatives, and the constraints on their capacity to act.They differ that competitive inertia specifies the number of market-leaningdeviations a company makes in trying to appeal customers and outfox players. Inertia will be said to be high when, relative to rivals of similar scale, companies make littlealterations in competitive practices. These actions together make up a firm's repertoire of competitive performance.

Similarly, competitive inertia isregarded as major strategic and more minor tactical types of actions, both of which are essential components of all competitive arsenals(Chen M.-J. , 1988);(Chen, Smith, \& Grimm, 1992).According 
to (Chen, Smith, \& Grimm, 1992) both cases areactions that are specific, concrete, and detectable. Tactical actions might include price changes, advertising campaigns, and incremental manufactured goods or service adjustments. Strategic actions may comprisekey facilities enlargement, mergers and acquisitions, strategic alliances, and important new products or services. In principle, strategic actions engross a greater expenditure of resources, along time prospect, and a greater departure from the current situation than perform tactical actions (Galbraith \& Kazanijan, 1986);(Dutton \& Duncan, 1987).

According to (Acharya, 2012), officials of international airlines based in Kathmandu say they observegreat potential for enlargement if some of the primary structural challenges to do with safety and infrastructure can be dealt with.

There has been little literature find that are related with the status of domestic airlines of Nepal that can be related with the competitive inertia. Therefore, the study of the current topic is very much relevant to enrich the literature also.

There has been little academic research carried out that is related with competitive inertia inNepali aviation industry. This study attempts to understand about competitive inertia in Nepali domestic aviation industry. The basic issues the study addresses are:

How does a tactical action lead to competitive inertia in domestic airlines of Nepal?

How does a strategic action lead to competitive inertia in domestic airlines of Nepal?

The objectives of the study are to understand the nature of competitive inertia in the Nepali aviation industry. For this purpose, the domestic airlines are chosen for the current study, as there is no sufficient sample for International airlines operating from Nepal.

Due to the hilly and mountainous terrain the importance of airlines becomes very high. However, airlines business involves high investment that leads to limited market players. This lead to monopolistic situation in the country like Nepal. Therefore, it is important to review the status of competitiveness of airlines in Nepalese context.

\section{Literature:-}

The literature on organizational change, culture, and decision making suggests three indispensable classes of factors that activate organizational action and, thus, competitive inertia. Main is the incentive to act, the motivational aspect of action discussed mostly by political decision philosophers and scholars of managerial designation(e.g. (Allison, 1971);(Schelling, 1971);(Staw, 1976);(Miller, Danney; Chen Ming Jer, 1994); and(Milliken \& Lant, 1991).Second is the perception of action requirements and substitutions, the knowledge component of action discussed by most learning philosophers(e.g. Cyert \& March,1963;, (Levitt \& March, 1988);(Huber G. P., 1991). Third are the constraints on managerial act, the potential component of act discussed by writers on organizational change, structure, and motion(e.g. (Hannan \& Freeman, 1984);(Tushman \& Romanelli, 1985);(Meyer \& Zucker, 1989);(Amburgey \& Minner, 19992); and (Miller, Danney; Chen Ming Jer, 1994).

According to (Starbuck \& Milliken, 1988); and(Milliken \& Lant, 1991)competitive inertia will be highest when there are very less incentives to act. Such incentives may be internal or external to the organization. The previous includes poor show that makes managers question the acceptability of their methods and motivates them to exploration for improvements.

Enticements to act that come from outside the firm might include escalating markets that give managers the selfassurance to invest in the pursuit of innovativechances(Miller D. , 1993). Inertia may also overcome when managers perceive relatively few alternative ways of performing(Huber G. P., 1991 March).

(Miller D. , 1993) and(Chen, Smith, \& Grimm, 1992)debate that the encounter in the literature about the impact of performance on inertia can be determined in part by making the dissimilarity between tactical and strategic actions. Further, to add opinionsthey state that, poor performance may induce tactical changes, as these are normally easy to make, entail few reversals in policy, and create little embarrassment. Strategic decisions may signal changes in policy that violate the preferences and reverse the riches of those in power. Even in the outcome of poor results, 
then, managers may resist captivating these actions. Strategic decisions will be less responsive to performance loss than tactical decisions(Miller, Danney; Chen Ming Jer, 1994).

As per (Miller, Danney; Chen Ming Jer, 1994) there is no strong relationship between tactical actions and market growth: Tactical changes may be no more motivated by an expanding than by a falling market. Strategic actionswill be far more likely when a growing market provides some large assurances of resources if a shrinking market signs tough times ahead.

(Danney \& Chen, 1994)conducteda study in the Aviation industry of U.S. using 21 types of actions to distinguishbetween tactical and strategic actions supporting competitive inertia. The variables they have taken for the study were:mergers and acquisitions, feeder and inter industry alliances, frequent flyer programs, and new airplane purchases. Similarly, activities that are easy to introduce and easily roll back with less impact to the organization are termed as Tactical actions. For the current study the following variables have been considered as tactical actions: Price Cut, Commission Rates changes for Agents, Promotions with Non Airlines Companies. Similarly, New Service introduction and Frequent Flyer program have been taken as strategic actions. Based on these variables the theoretical framework is designed asgiven in Fig.1.

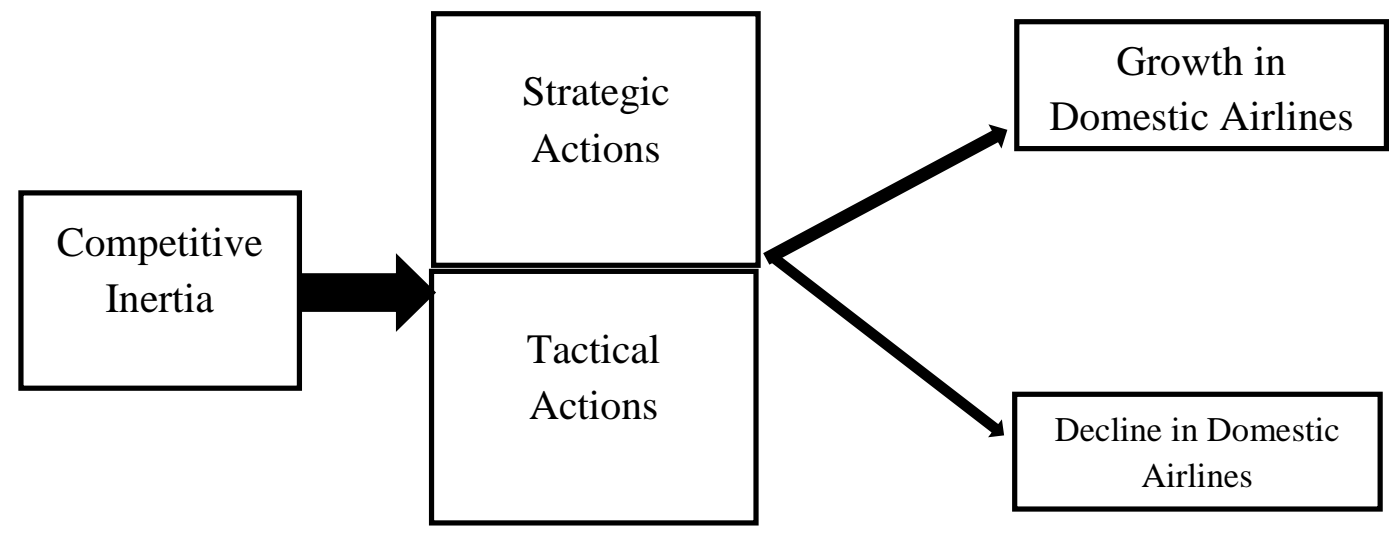

Fig 1:-Theoretical Framework of Competitive Inertia

Based on the above theoretical framework and the research questions the following hypothesis have been formulated and tested.

Hypothesis 1: Strategic actions related tocompetitive inertia results in growth of domestic airlines.

Hypothesis 2: Tactical actions related to competitive inertia and decline in domestic airlines.

\section{Methods:-}

In this study the data were collected in two stage using convenience sampling method. In the first stage, fifty respondents responded to the structured questionnaire at Tribhuvan international airport domestic terminal. For this purpose the questionnaire was used by (Shrestha, 2014). Based on the analysis of responses from the first stage of data, three airlines - Buddha air, Yeti airlines and Nepal airlines- were selected for the second stage of data collection. In this stage, responses on structured questionnaire used by (Sturesson, 2010) was used. Besides questionnaire, unstructured interview was also carried out with the respondents, who were member of travel agents in Kathmandu Valley and are doing domestic ticketing of the selected airlines.

Based on the response three top airlines: Buddha Air, Nepal Airlines Corporation and Yeti airlines were selected for second stage of data collection. The second stage of data collection was focus of the components of tactical and strategic actions adopted by the domestic airlines.

\section{Results:-}

From the analysis of the data collected at the first stage at Tribhuvan international airport domestic terminal it was found that 57 responses with $95 \%$ response rate have returned the questionnaire duly filled. Of the respondents 
$19.30 \%$ were female while $80.70 \%$ were male, $24.5 \%$ were under SLC, $54 \%$ were bachelor level and $21.5 \%$ of respondent were university graduate.

Table 1:- Correlations between Passenger Movement and Competitive inertia

\begin{tabular}{|c|c|c|c|c|}
\hline Indicator & $\begin{array}{c}\text { Passenger } \\
\text { Movement }\end{array}$ & Price for ticket & $\begin{array}{c}\text { Commission to } \\
\text { Agents }\end{array}$ & $\begin{array}{c}\text { Promotion with non- } \\
\text { airlines companies }\end{array}$ \\
\hline Passenger Movement & 1 & -.028 & .396 & .153 \\
\hline Sig. (2-tailed) & & $.931^{*}$ & $.202^{*}$ & $.634^{* *}$ \\
\hline Number of Observation & 12 & 12 & 12 & 12 \\
\hline
\end{tabular}

Remarks:(* significant at 5\%, and ** significant at 10\%)

The table above shows that passenger movement is correlated with variables of competitive inertia. The passenger movement is significant with commission to the agents and price of ticket at 5\% level of significant. Similarly, promotion with non-airlines is significant at $10 \%$ level of significant. This supports our first hypothesis, Strategic actions related to competitive inertia results in growth of domestic airlines.

From the correlation analysis, it is seen that passenger movement is not significant with frequent flyer program and new service. Hence we reject our second hypothesis, Tactical actions related to competitive inertia and decline in domestic airlines.

Table 2:- Correlations between Passenger Movement and Tactical inertia

\begin{tabular}{|c|c|c|c|}
\hline Indicator & Passenger Movement & Frequent flyer programme & New Services \\
\hline Passenger Movement & 1 & .019 & .539 \\
\cline { 2 - 4 } & Sig. (2-tailed) & .953 & .070 \\
\cline { 2 - 4 } & 12 & 12 & 12 \\
\hline
\end{tabular}

Remarks:(* significant at 5\%, and ** significant at $10 \%)$

\section{Discussion:-}

The aim of this study was to examine the correlation between competitive inertia and passenger movement in Nepali domestic airlines. Using a field study of 76 respondents it was found that there exist significant relationships. Significant relationship between past performance and tactical actions while moderate relationship between past performance and strategic actions was found. There is an indication that domestic aviation industry in Nepal shows an association with tactical actions.Similarly, aviation industry should focus on the pricing decision, as the price has significant negative relation between passenger movement and pricing decision. This is why aviation companies has various pricing package to offer- full fare, economic price, cost on cancelation and millage is also different based on price of ticket.

Similar study was carried out by ARTUĞER (2013) entitled "The effect of Frequent Flyer Program on Customer Loyalty". The report suggests that members consider the intangible rewards more important than the tangible benefits. Therefore, focus should be given to the millage program as it has significant relationship in the tactical action.

As there is no academic study carried out in competitive inertia in Nepali Organizations, hence this study can be a stepping stone for further research in any form of inertia in Nepali organizations. Further, many of the results, can be understood through the lenses of two separate replicas of organizational learning what might be called "reactive" and "experimental" learning March (1991).

Consistent with the model of reactive learning as mentioned by Lindblom, (1959), Cyert \& James (1963) inertia in tactical actions was very much a function of organizational success. Tactical adjustments were more common when poor performance signaled the need to act Cyert \& James, (1963),Levinthal \& James (1981), Lant \& Montogomery (1987). In our study tactical actions such as promotion with non-airlines was found to be introduced. Even there are very little promotional activities carried out by airlines. The reactive learning model functioned less well, however, in forecasting inertia in strategic actions. 


\section{Limitation:-}

The current study is limited in many ways,most important limitationsis data collection. It was carried out based on the questionnaire used by(Artuger, 2013)and(Shrestha, 2014). Therefore, the representativeness of the questionnaire may limit the data collections. However, to cater this limitation, unstructured questionnaire was also administered during the data collection phase. Similarly, sample collected may not be sufficient for the generalization of the study. Further, data collection was done only within Kathmandu valley, therefore heterogeneity of respondents may be missing in this study. The domestic aviation industry is dominated by a few players in the market, therefore for first level of study in Nepali context may not be appropriate.

Despite of such limitation, we expect that this study will lay foundation on study on competitive or any other form of inertia in Nepali organization as well as global context. Further, this study will also help to further elaborate the concept of inertia. Continued research is necessary before recommending official or non-official commendation of inertia in Nepali domestic airlines or other airlines in the world.

\section{References:-}

1. Acharya, A. (2012). Nepal by Air: International Aiirlines See Big Potential for Growth in Kathmandu Trafic. Nepali Times.

2. Allison, G. (1971). The Essence of Decision. New York, Wiley.

3. Amburgey, T. L., \& Minner, A. S. (19992). Strategic Momentum: The effects of repetitive Positional and Contextual Momentum on Merger Activity. Strategic Management Journal 13, 335-348.

4. ARTUĞER, A. P. (2013). THE EFFECT OF FREQUENT FLYER PROGRAMS ON CUSTOMER LOYALTY. The International Journal of Social Sciences, 33.

5. Chen, M. J., Smith, K. G., \& Grimm, C. (1992). Action Characteristics as Predictors of Competitive Responses. Management Science, 38, 439-455.

6. Chen, M.-J. (1988). Competitive Strategic Interaction: A Study of Competitive Actions and Responses. University of Maryland, Unpublished Doctoral Disesrtation.

7. Cyert, R. M., \& James, M. G. (1963). A Behavioural Theory of the Firm. Englewood Cliffs, NJ: Prentic-Hall.

8. Cyert, R. M., \& March, J. G. (1963). A Behavioral Theory of the Firm. Englewood Cliffs, NJ: Prentic- Hall.

9. Danney, M., \& Chen, M.-J. (1994). Sources and Consequences of Competitive Inertia: A Study of the U. S. Airlines Industry. Administrative Science Quarterly. Vol 39, 1-23.

10. Dutton, J. E., \& Duncan, R. (1987). The Creation of Monentum for Change Through the Process of Strategic Diagonisis. Strategic Management Journal, 8, 279-295.

11. Galbraith, J. R., \& Kazanijan, R. (1986). Strategy Implementation: Structure, Systems and Process. St. Paul MN West.

12. Hannan, M. T., \& Freeman, J. H. (1984). Structural Inertia and Oranizational Change. American Sociological Review 49, 149-164.

13. Huber, G. P. (1991 March). Organizational Learning. Organizational Science,2, 88-115.

14. Huber, G. P. (1991). Organizational Learning. Organizational Science, 2, 88-115.

15. Lant, T. K., \& Montogomery, D. B. (1987). Learing from Strategic Sucess and Failure. Journal of Business Research 15, 503-518.

16. Levinthal, D. A., \& James, M. G. (1981). A Model of Adaptive Organizational Search. Journal of Economic Behavior and Organization 2, 307-333.

17. Levitt, B., \& March, J. G. (1988). Organizational Learning. Annual Review of Sociology, 14 (pp. 319-340). Palo Alto: Annual Review.

18. Lindblom, C. E. (1959). The Science of Muddling-through. Public Administration Review, 19, 58-65.

19. March, J. G. (1991). Exproration and Exploitation in Organization Learning. Organizational Science 2, 71-87.

20. Meyer, M. W., \& Zucker, L. G. (1989). Permanently Failing Orngainzations. Beliverly Hills CA: Sage Publication.

21. Miller, D. (1993). The Artichitecuture of Simplicity. Academy of Management Review, 18, 116-138.

22. Miller, D., \& Friesen, P. H. (1984). Organizations: A Quantum View. Englewood Cliffs, NJ: Pentice Hall.

23. Miller, Danney; Chen Ming Jer. (1994, March). Sources and Consequences of Competetive Inertia: A Study of the U.S. Airline Industry. Administrative Science Quarterly, 39 , p. 1.

24. Milliken, F. J., \& Lant, T. K. (1991). The Impact of an Organization's Recent Performance History on Strategic Persistance and Change. Advance Jouranal in Strategic Management 7, 129-156.

25. Milliken, F. J., \& Lant, T. K. (1991). The Impact of an Organization's Recent Preformance History on Strategic Peresistance and Chance. Advances in Strategic Management 7, 129-156. 
26. Milliken, F. J., \& Lant, T. K. (1991). The Impact of an Organization's Recent Preformance History on Strategic Presistance and Change. Advances in Stragegic Manangement 7, 129-156.

27. Schelling, T. C. (1971). The Strategy of Conflict. Cambridge, MA: Harvard University Press.

28. Shrestha, B. R. (2014, October ). Airline Brand Loyalty: A case study involving the three airlines- SAS, Norwegian and Wideroe. UiT The Arctic University of Norway. Hansine Hansens , veg 18, 9019 Troms $\emptyset$, Norway.

29. Starbuck, W. H., \& Milliken, F. J. (1988). Challenger: Finetuning the Odds until Something Breaks. Journal of Management Studies, 25, 319-340.

30. Staw, B. M. (1976). Keen-deep in the Big Muddy : A Study of Escalating Commitment to a Chosen Course of Action. Organizational Behavior and Human Performance, 16, 27-44.

31. Sturesson, V. (2010, December). Can the low cost boom in aviation reach long distance destinations? Gavel, Sweeden: Thesis: Study program in Master in Business Administration, University of Gavel, Sweeden.

32. Tushman, M. L., \& Romanelli, E. (1985). Organizational Evolution: A Metamorphosis Model of Convergence and Reorientaion. Greenwich, CT: JAI Press.

Annexes:-

Table 3:- Response on Airlines Travel by Respondents

\begin{tabular}{|l|l|l|l|l|l|}
\hline SN & Name of Airlines & No of Respondent & SN & Name of Airlines & No of Respondent \\
\hline 1 & Buddha Air & 22 & 5 & Simrik Airlines & 5 \\
\hline 2 & Nepal Airlines & 10 & 6 & Manag Air & 5 \\
\hline 3 & Yeti Airlines & 8 & 7 & Sita Air & 0 \\
\hline 4 & Air Dynasty & 4 & 8 & Shree Airlines & 3 \\
\hline
\end{tabular}

Table 4:- General Impression of Respondents on Nepalese Airlines

\begin{tabular}{|c|c|c|c|}
\hline Airlines & Excellent & Good & Total \\
\hline Buddha Air & 28 & 27 & 55 \\
\hline Nepal Airlines Corporation & 12 & 13 & 25 \\
\hline Yeti Air & 11 & 35 & 36 \\
\hline Shree Airlines & 2 & 17 & 19 \\
\hline Air Dynasty & 6 & 16 & 22 \\
\hline Simrik Airlines & 4 & 23 & 27 \\
\hline Manag Air & 0 & 16 & 16 \\
\hline Sita Airlines & 1 & 9 & 10 \\
\hline
\end{tabular}

Table 5:- Correlations Matrix-I

\begin{tabular}{|l|l|l|l|l|l|}
\hline \multicolumn{2}{|c|}{} & $\begin{array}{l}\text { Passenger } \\
\text { Movement }\end{array}$ & $\begin{array}{l}\text { Price for } \\
\text { ticket }\end{array}$ & $\begin{array}{l}\text { Commission to } \\
\text { Agents }\end{array}$ & $\begin{array}{l}\text { Promotion with non- } \\
\text { airlines companies }\end{array}$ \\
\hline $\begin{array}{l}\text { Passenger } \\
\text { Movement }\end{array}$ & $\begin{array}{l}\text { Pearson } \\
\text { Correlation }\end{array}$ & 1 & -.028 & .396 & .153 \\
\cline { 2 - 6 } & Sig. (2-tailed) & & $.931^{*}$ & $.202^{*}$ & $.634^{* *}$ \\
\cline { 2 - 6 } & $\mathrm{N}$ & 12 & 12 & 12 & 12 \\
\hline
\end{tabular}

(* significant at 5\%, and ** significant at $10 \%$ )

Table 6:- Correlations Matrix-II

\begin{tabular}{|l|l|l|l|l|}
\hline \multicolumn{2}{|c|}{} & $\begin{array}{l}\text { Passenger } \\
\text { Movement }\end{array}$ & Frequent flyer programme & $\begin{array}{l}\text { New } \\
\text { Services }\end{array}$ \\
\hline \multirow{2}{*}{$\begin{array}{l}\text { Passenger } \\
\text { Movement }\end{array}$} & Pearson Correlation & 1 & .019 & .539 \\
\cline { 2 - 5 } & Sig. (2-tailed) & & $.953^{*}$ & $.070^{*}$ \\
\cline { 2 - 5 } & $\mathrm{N}$ & 12 & 12 & 12 \\
\hline Remarks: $*$ Correlation is significant at the 0.05 level (2-tailed) & \\
\hline
\end{tabular}

